\title{
Psoriatic Arthritis in Psoriasis Patients: Evaluation of Clinical and Radiological Features
}

\author{
Psoriasisli Hastalarda Psoriatik Artrit: Klinik ve Radyolojik Özelliklerin Değerlendirilmesi \\ Hatice Reşorlu, Zerrin Öğretmen*, Sevilay Kılıç*, Ayla Akbal, Coşkun Zateri, Sibel Cevizci** \\ Çanakkale Onsekiz Mart University Faculty of Medicine, Department of Physical Medicine and Rehabilitation, Çanakkale, Turkey \\ *Çanakkale Onsekiz Mart University Faculty of Medicine, Department of Dermatology, Çanakkale, Turkey \\ **Çanakkale Onsekiz Mart University Faculty of Medicine, Department of Public Health, Çanakkale, Turkey
}

Summary

Objective: The purpose of this study was to perform radiological and clinical determination of the presence of psoriatic arthritis (PsA) in patients with psoriasis and to evaluate associations with clinical findings.

Materials and Methods: The medical files of 72 patients with psoriasis presenting to our clinic between years $2009-2014$ with a prediagnosis of PsA were reviewed retrospectively. Hand, foot and sacroiliac joint radiograms were evaluated by a radiologist who was blinded to the patient's clinical status and who is experienced on musculoskeletal radiology. Patients with psoriasis were divided into two groups according to the presence of arthritis which was determined based on radiographic findings or on Classification Criteria for Psoriatic Arthritis (CASPAR) criteria. All patients' demographic characteristics, length of disease, nail involvement, smoking-alcohol consumption were recorded. Results: The mean age of all patients was $47.24 \pm 14.61$ years, and the mean duration of disease was $14.13 \pm 11.92$ years. Smoking and alcohol consumptions were determined in $54.2 \%(n=39)$ and $23.6 \%(n=17)$ of the cases, respectively. Nail involvement was determined in $56.9 \%(n=41)$ of the cases. PsA was determined based on radiological findings in $58.3 \%(n=42)$ of the patients. The mean age and age at onset of disease were higher in PSA (+) patients than in radiologically non-PsA subjects. Based on clinical findings, PSA based on CASPAR criteria was determined in only $18.1 \%(n=13)$ of all patients.

Conclusion: A higher level of PsA was determined using radiological evaluation in this study. The main cause of this condition is the existence of asymptomatic-subclinical patients. A detailed medical history should therefore be taken from patients, and good clinical evaluation is very important. Radiological and clinical evaluation should be performed together in the diagnosis.

Keywords: Psoriasis, psoriatic arthritis, radiographic finding

\section{$\ddot{O z}$}

Amaç: Bu çalışmanın amacı psoriasisli hastalarda, psoriatik artritin (PsA) varlığını klinik ve radyolojik açıdan belirlemek ve klinik bulgularla ilişkisini değerlendirmektir.

Gereç ve Yöntem: Çalışmamızda 2009-2014 yılları arasında polikliniğimize PsA ön tanısı ile yönlendirilen 72 psoriasis tanılı hastanın dosyaları retrospektif olarak incelendi. Hastaların el, ayak ve sakroiliak eklem grafileri, hangi hastalarda klinik olarak PsA olduğunu bilmeyen, kas iskelet sistemi radyolojisinde tecrübeli bir radyolog tarafından okundu. Tüm psoriasisli hastalar, radyografik bulgulara ve Classification Criteria for Psoriatic Arthritis (CASPAR) kriterlerine göre değerlendirilerek PsA olan ve olmayan olarak iki gruba ayrıldı. Tüm hastaların demografik verileri, hastalık süresi, tırnak tutulumu, sigara-alkol kullanımı kayıt edildi.

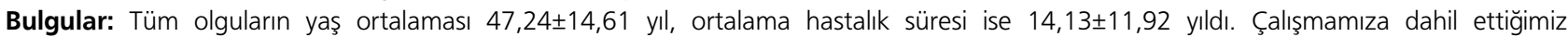
hastaların \%54,2'si (n=39) sigara, \%23,6'sı ( $n=17)$ alkol kullanmaktaydı. Hastaların \%56,9'unda ( $n=41)$ tırnak tutulumu mevcuttu. Hastaların \%58,3'ünde ( $n=42$ ) radyolojik bulgulara göre PsA tespit edildi. Bu olgularda yaş ortalaması ve hastalığın başlangıç yaşı, radyolojik olarak PsA olmayanlara göre daha yüksekti. Klinik olarak tüm hastaların sadece \%18,1'inde ( $n=13)$ CASPAR kriterlerine göre PsA saptandı.

Sonuç: Radyolojik değerlendirmeye göre PsA olarak nitelendirdiğimiz hastaların oranı yüksek bulunmuştur. Bu durumun ana nedeni asemptomatik-subklinik seyirli hastaların varlığıdır. Bu nedenle psoriasis hastalarında detaylı öykü alınması ve iyi klinik muayene yapılması önemlidir. PsA tanısında radyolojik ve klinik değerlendirme birlikte kullanılmalıdır.

Anahtar kelimeler: Psoriasis, psoriatik artrit, radyolojik bulgu

Address for Correspondence/ Yazışma Adresi: Hatice Reşorlu MD, Çanakkale Onsekiz Mart University Faculty of Medicine, Department of Physical Medicine and Rehabilitation, Çanakkale, Turkey Phone: +90 5054548721 E-mail: drresorlu@gmail.com Received/Geliş Tarihi: 03.01.2016 Accepted/Kabul Tarihi: 19.01.2016

Turkish Journal of Osteoporosis, published by Galenos Publishing. / Türk Osteoporoz Dergisi, Galenos Yayınevi tarafindan basılmıştır. 


\section{Introduction}

Psoriatic arthritis (PsA) is a chronic inflammatory rheumatic disease associated with psoriasis in which rheumatoid factor is negative (1). It affects men and women equally, with a prevalence ranging between $0.3-1 \%$ (2). In addition to peripheral joint and axial skeleton involvement, osteoarticular findings such as enthesitis, tenosynovitis and dactylitis may also be seen in PsA (3). Joint involvement in PsA ranges from monoarthritis to destructive polyarthritis. Cutaneous lesions are reported to be present before arthritis in $67 \%$ of the cases (1). The diagnosis of PsA may be difficult due to the broad clinical spectrum of arthritis, the possibility of earlier cutaneous findings and the absence of recognized specific diagnostic criteria $(3,4)$. It is therefore important to obtain detailed anamnesis from patients with psoriasis and for good clinical evaluation to be performed. That evaluation must investigate established risk factors for arthritis, such as the presence of cutaneous and nail involvement and family history (5).

This study was investigated whether radiographic findings in patients with psoriasis would help predict the identification of patients with PsA. We also intended to determine factors associated with arthritis in patients diagnosed with PsA on the basis of radiological findings.

\section{Materials and Methods}

This study was performed as a retrospective evaluation of 72 patients diagnosed with psoriasis in the department of dermatology in our hospital between years 2009-2014 and referred to the department of physical medicine and rehabilitation with a preliminary diagnosis of PsA. Patients' clinical data and laboratory findings were obtained from medical files and imaging findings from the radiology archive. The present study was conducted with approval of the local Ethics Committee and suitable with Declaration of Helsinki.

Patients' hand, foot and sacroiliac joint radiographs were evaluated by a radiologist (experienced in musculoskeletal radiology) blinded to their clinical status. In terms of presence of PsA, patients were divided into two groups, those identified by radiology and those identified using Classification Criteria for Psoriatic Arthritis (CASPAR) criteria. The two groups were compared in terms of demographic data, articular and extraarticular findings and clinical pictures. The relationship between the psoriasis area severity index (PASI) measured by lesion distribution and arthritis was evaluated.

The data obtained were analyzed on SPSS version 19.0 software. Variables' compatibility with normal distribution was examined using the Kolmogorov-Smirnov and Shapiro-Wilk tests. Descriptive data were expressed as mean, standard deviation, media, minimum, maximum, frequency and percentage values. In comparisons of patients with or without PsA, the MannWhitney $U$ test was used for constant variables and Fisher's Exact test for categorical variables. $\mathrm{P}$ values $<0.05$ were considered statistically significant.

\section{Results}

Thirty-six females $(50.0 \%)$ and 36 males (50.0\%) were included in the study. The mean age of the patients was $47.24 \pm 14.61$ years (14-85). The mean age at onset of disease was $32.97 \pm 16.42$ years $(5.00-80.00)$, and the mean length of disease $14.13 \pm 11.92$ years (1-55). Histories of smoking and alcohol consumption were present in $54.2 \%(n=39)$ and $23.6 \%$ $(n=17)$.

Nail involvement was present in $56.9 \%(n=41)$ of patients with psoriasis, and presence of arthritis, determined clinically and radiologically, was not correlated with nail involvement $(p=0.371, p=0.968$, respectively). PsA was determined in $58.3 \%(n=42)$ of patients based on radiological findings and in $18.1 \%(n=13)$ based on CASPAR criteria. The mean age was higher among patients with PSA based on radiological findings. At hand radiography evaluation, radiological changes suggesting PsA were determined in $29.2 \%(n=21)$ of patients. In terms of foot radiographs, $41.7 \%(n=30)$ were normal, enthesopathy+calcaneal spur was observed in $55.6 \%(n=40)$ and radiological changes suggestive of PsA in $2.7 \%(n=2)$. Sacroiliac joint involvement was positive in $48.6 \%(n=35)$ of patients.

The determination of peripheral arthritis in 6, sacroilitis in 9 and enthesitis in 11 of the 13 patients diagnosed with PsA on the basis of CASPAR criteria. Nail involvement was observed in 9 cases in this group and uveitis in one. No correlation was determined between the presence of arthritis and PASI scores in patients with PSA diagnosed on the basis of CASPAR criteria $(p=0.515)$.

Demographic and clinical characteristics of patients with or without PsA according to radiological findings are shown in Table 1.

Demographic and clinical characteristics of patients with or without PsA according to CASPAR criteria are shown in Table 2.

\section{Conclusion}

PSA is a chronic inflammatory disease reducing the quality of life by causing deformity and joint restriction. Clinical and radiological findings are used to assess joint involvement in the disease (6). Radiological assessment is among the important parameters in PsA and can show changes such as erosion, periosteal reaction, joint space narrowing, lysis, ankylosis and enthesitis (7). Frequent radiographic examination of patients with psoriasis at risk of PsA is not recommended due to the harm of radiation. This is the major cause of limitation for the monitoring of changes in radiographic findings during the development of arthritic changes.

A broad range of $6-42 \%$ has been reported for the prevalence of PsA in patients with psoriasis (2). We determined a presence of arthritis in $58.3 \%(n=42)$ of cases using radiology and in $18.1 \%(n=13)$ on the basis of CASPAR criteria. More than one factor may be involved in the higher determination of presence of PSA at radiological examination. We think that 
the most important factor increasing radiological diagnosis of PsA is the sacroiliac involvement of $48.6 \%$. Similarly to our findings, high levels of $34-78 \%$ have been reported for sacroiliitis demonstrated through radiology $(8,9)$. The high level of detection of sacroiliitis is particularly associated with the sensitivity of magnetic resonance imaging (MRI) at joint imaging. Studies by Harvie et al. (10) and Maldonado-Cocco et al. (11) detected sacroiliac joint abnormality in $10-25 \%$ of patients using conventional radiography. Williamson et al. (12) observed sacroiliac joint involvement using MRI in 26 out of 68 patients with PsA, but reported clinical sacroiliitis in only 10 patients (38\%). In a study on 133 patients, Kaçar et al. (13) detected presence of sacroiliitis in $26 \%(n=34)$ using radiology. They also reported that $62 \%$ of the patients in whom they detected sacroiliitis were clinically asymptomatic (13).

Another radiological finding seen in PSA is peripheral arthritis in various forms, from monoarthritis to polyarthritis. Erosive arthropathy of the distal interphalangeal joints is one important radiological finding (15). Twenty-one of our patients were diagnosed with PSA at hand radiography. We think that the radiological findings in some of these may have been secondary to osteoarthritis. Mean age in our patient group with PsA diagnosed radiologically was $50.05 \pm 14.69$ years, and the patients being in the advanced age group supports this view. The level of patients with arthritis detected at foot radiography was low (2.8\%), but high levels of enthesopathic changes were determined (55.6\%). It has been reported that the rates of enthesitis in the bone attachment areas of tendon, ligament, fascia and articular capsule were $20-25 \%$ in patients with psoriasis and $25-53 \%$ in patients with PsA $(16,17)$. The most commonly affected areas are the achilles tendon, the plantar fascia, the femoral trochanters, ischial tuberosities, the medial and lateral malleolus, the ulna olecranon and the patella anterior $(16,17)$. Gisondi et al. (18) referred to the presence of subclinical enthesopathy in patients with psoriasis with no clinical findings of arthritis.

Table 1. Demographic and clinical characteristics of patients with or without psoriatic arthritis according to radiological findings

\begin{tabular}{|c|c|c|c|}
\hline & $\begin{array}{l}\text { PsA cases }(n=42) \\
n(\%)\end{array}$ & $\begin{array}{l}\text { Non-PsA cases }(n=30) \\
n(\%)\end{array}$ & $\mathbf{p}^{*}$ \\
\hline Female & $22(61.1)$ & $14(38.9)$ & \multirow[t]{2}{*}{0.633} \\
\hline Male & $20(56.6)$ & $16(44.4)$ & \\
\hline Smoking & $23(59.0)$ & $16(59.0)$ & 0.905 \\
\hline Alcohol consumption & $11(64.7)$ & $6(35.3)$ & 0.542 \\
\hline \multirow[t]{2}{*}{ Nail involvement } & $24(58.5)$ & $17(41.5)$ & 0.968 \\
\hline & Mean \pm SD & Mean \pm SD & $\mathbf{p}^{* *}$ \\
\hline Age (years) & $50.05 \pm 14.69$ & $43.30 \pm 13.79$ & 0.053 \\
\hline Age at onset (years) & $35.74 \pm 16.62$ & $29.10 \pm 15.60$ & 0.091 \\
\hline Duration of disease (years) & $14.07 \pm 12.37$ & $14.20 \pm 11.46$ & 0.964 \\
\hline
\end{tabular}

Table 2. Demographic and clinical characteristics of patients with or without psoriatic arthritis according to classification criteria for psoriatic arthritis criteria

\begin{tabular}{|c|c|c|c|}
\hline & $\begin{array}{l}\text { PsA cases }(n=13) \\
n(\%)\end{array}$ & $\begin{array}{l}\text { Non-PsA cases }(n=59) \\
n(\%)\end{array}$ & $p^{*}$ \\
\hline Female & $7(19.4)$ & $29(80.6)$ & 0.759 \\
\hline Male & $6(16.7)$ & $30(83.3)$ & \\
\hline Smoking & $4(10.3)$ & 35 (89.7) & 0.073 \\
\hline Alcohol consumption & $4(23.5)$ & $13(76.5)$ & 0.490 \\
\hline \multirow[t]{2}{*}{ Nail involvement } & $9(22.0)$ & $32(78.0)$ & 0.371 \\
\hline & Mean \pm SD & Mean \pm SD & $\mathbf{p}^{* *}$ \\
\hline Age (years) & $52.31 \pm 16.39$ & $46.12 \pm 14.10$ & 0.278 \\
\hline Age at onset (years) & $35.69 \pm 19.31$ & $32.37 \pm 15.85$ & 0.709 \\
\hline Duration of disease (years) & $16.62 \pm 13.83$ & $13.58 \pm 11.51$ & 0.572 \\
\hline Mean PASI score & $9.85 \pm 6.42$ & $12.04 \pm 8.80$ & 0.515 \\
\hline
\end{tabular}


This may account for the high level of radiologically detected enthesis in our patients.

Another clinical finding seen in patients with psoriasis is nail changes such as pitting, onycholysis and hyperkeratosis. Nail changes are seen in $40 \%$ of patients with psoriasis and $80 \%$ of patients with PsA, and are regarded as a predictor of development of PsA (19). We identified nail involvement in $56.9 \%$ of our patients. However, we determined no correlation between nail involvement and PsA. We think that this derives from the low number of patients.

Asymptomatic-subclinical PsA may be seen in some psoriasis patients with radiological findings. In contrast, false positive results may also be observed due to osteoarthritis developing with age. A detailed medical history should therefore be taken from patients with arthritis, and good clinical evaluation is very important. Delayed diagnosis impairs quality of life by causing joint deformities and restriction.

The main limitation of this study is the insufficient number of patients. Its retrospective nature also limits the clinical factors we were able to analyze. In conclusion, we think that radiological and clinical evaluation should be performed together in the diagnosis and monitoring of PsA, and that diagnosis should be confirmed using imaging techniques.

\section{Ethics}

Ethics Committee Approval: Çanakkale Onsekiz Mart University Faculty of Medicine Ethical Committe approval was obtained, Informed Consent: Informed consent was obtained from all patients.

Peer-review: Internal peer-reviewed.

\section{Authorship Contributions}

Surgical and Medical Practices: Hatice Reşorlu, Concept: Zerrin Öğretmen, Sevilay Kılıç, Design: Sevilay Kılıç, Ayla Akbal, Data Collection or Processing: Coşkun Zateri, Sibel Cevizci, Analysis or Interpretation: Coşkun Zateri, Sibel Cevizci, Literature Search: Zerrin Öğretmen, Ayla Akbal, Writing: Hatice Reşorlu, Sevilay Kılıç.

Conflict of Interest: No conflict of interest was declared by the authors.

Financial Disclosure: The authors declared that this study received no financial support.

\section{References}

1. Duarte GV, Faillace $C$, Freire de Carvalho J. Psoriatic arthritis. Best Pract Res Clin Rheumatol 2012;26:147-56.

2. Gladman DD, Antoni C, Mease P, Clegg DO, Nash P. Psoriatic arthritis epidemiology, clinical features, course and outcome. Ann Rheum Dis 2005;64(Suppl 2)14-7.

3. Gottlieb A, Korman NJ, Gordon KB, Feldman SR, Lebwohl M, Koo JY, et al. Guidelines of care for the management of psoriasis and psoriatic arthritis: Section 2. Psoriatic arthritis: overview and guidelines of care for treatment with an emphasis on the biologis. J Am Acad Dermatol 2008;58:851-64.

4. Caso F, Costa L, Atteno M, Del Puente A, Cantarini L, Lubrano $E$, et al. Simple clinical indicators for early psoriatic arthritis detection. Springerplus 2014;3:759.

5. Wilson FC, Icen M, Crowson CS, McEvoy MT, Gabriel SE, Kremers HM. Incidence and clinical predictors of psoriatic arthritis in patients with psoriasis: a population-based study. Arthritis Rheum 2009;61:233-9.

6. Gladman DD, Helliwell P, Mease PJ, Nash P, Ritchlin C, Taylor W. Assesment of patients with psoriatic arthritis. a review of currently available measures. Arthritis Rheum 2004;50:20-35.

7. Sianis F, Farewell VT, Cook RJ, Schentag CT, Gladman DD. Clinical and radiological damage in psoriatic arthritis. Ann Rheum Dis 2006;65:478-81.

8. Baek HJ, Yoo CD, Shin KC, Lee YJ, Kang SW, Lee EB, et al. Spondylitis is the most common pattern of psoriatic arthritis in Korea. Rheumatol Int 2000;19:89-94.

9. Battistone MJ, Manaster BJ, Reda DJ, Clegg DO. The prevalence of sacroiliitis in psoriatic arthritis: new perspectives from a large, multicenter cohort. A Department of Veterans Affairs Cooperative Study. Skeletal Radiol 1999;28:196-201.

10. Harvie JN, Lester RS, Little AH. Sacroiliitis in severe psoriasis. AJR Am J Roentgenol 1976;127:579-84.

11. Maldonado-Cocco JA, Porrini A, Garcia-Mortoe O. Prevalence of sacroiliitis and ankylosing spondylitis in psoriasis patients. J Rheumatol 1978;5:311-3.

12. Williamson L, Dockerty JL, Dalbeth N, McNally E, Ostlere S, Wordsworth BP. Clinical assessment of sacroiliitis and HLA-B27 are poor predictors of sacroiliitis diagnosed by magnetic resonance imaging in psoriatic arthritis. Rheumatology (Oxford) 2004;43:85-8.

13. Kaçar C, Sezer I, Kocabaş H, Cay HF, Cevikol C, Alpsoy E, et al. Sacroiliac joint involvement in psoriasis. Rheumatol Int 2010;30:1263-6.

14. Helliwell PS, Taylor WJ. Classification and diagnostic criteria for psoriatic arthritis. Ann Rheum Dis 2005;64(Suppl 2):3-7.

15. Taylor W, Gladman D, Helliwell P, Marchesoni A, Mease P, Mielants $\mathrm{H}$, et al. Classification criteria for psoriatic arthritis: development of new criteria from a large international study. Arthritis Rheum 2006;54:2665-73.

16. Dhir V, Aggarwal A. Psoriatic arthritis: a critical review. Clin Rev Allergy Immunol 2013;44:141-8.

17. Cantini F, Salvarani C, Olivieri I, Macchioni L, Niccoli L, Padula A, et al. Distal extremity swelling with pitting edema in psoriatic arthritis: a case-control study. Clin Exp Rheumatol 2001;19:291-6.

18. Gisondi P, Tinazzi I, El-Dalati G, Gallo M, Biasi D, Barbara LM, et al. Lower limb enthesopathy in patients with psoriasis without clinical signs of arthropathy: a hospital-based case-control study. Ann Rheum Dis 2008;67:26-30.

19. Raposo I, Torres T. Nail psoriasis as a predictor of thedevelopment of psoriatic arthritis. Actas Dermosifiliogr 2015;106:452-7. 